\title{
Learning Styles of Undergraduate Medical Students
}

\author{
Estilos de aprendizaje en estudiantes de medicina
}

Received: 07/05/2015 | Accepted: 16/11/2017

\author{
Michelle Cortés Barréa \\ Pontificia Universidad Javeriana, Colombia \\ ORCID: http://orcid.org/0000-0001-5881-6123 \\ Javier Fabricio Guillén Olaya \\ Pontificia Universidad Javeriana, Colombia \\ ORCID: http://orcid.org/0000-0001-6185-215X
}

a Correspondence: michelle.cortes@javeriana.edu.co

\begin{abstract}
Introduction: According to the experiential learning theory, each person develops a learning style that characterizes his/her preferred way to acquire and transform experiences to create knowledge. The objective of this study was to identify the learning styles of undergraduate medical students. Methods: The Kolb Learning Style Inventory was applied to first-year medical students at the Pontificia Universidad Javeriana (Bogotá, Colombia) during the second period of 2009. Results: 204 students completed the questionnaire (the average age was 18.5 years; $55 \%$ were women). Students preferred the abstract styles of learning, including assimilating (47\%) and converging (27\%) styles. Conclusions: Having information about medical students learning style preferences can help educators to design teaching strategies that promote a more effective learning. Teachers should provide a variety of learning contexts to stimulate the strengthening of their abilities.

Keywords

learning; models/educational; education/medical/undergraduate.
\end{abstract}

\section{RESUMEN}

Introducción: Según la teoría del aprendizaje basada en la experiencia, cada persona desarrolla un estilo de aprendizaje que caracteriza su forma de adquirir y transformar experiencias para crear conocimiento. El objetivo de este trabajo fue identificar los estilos de aprendizaje de los estudiantes de medicina. Métodos: Se aplicó el Inventario de Estilos de Aprendizaje a los estudiantes de los tres primeros semestres de Medicina de la Pontificia Universidad Javeriana durante el segundo semestre del 2009. Resultados: Se encuestaron 204 estudiantes (la edad media fue 18,5 años; $55 \%$ eran mujeres). Prevalecieron los estilos de aprendizaje abstractos, que incluyen el estilo asimilador (47\%) y el convergente (27\%). Discusión: Conocer el estilo de aprendizaje de los estudiantes puede ayudar a los profesores a diseñar estrategias de enseñanza que favorezcan un aprendizaje más efectivo. Paralelamente, conviene proporcionarles una variedad de contextos de aprendizaje que promuevan el fortalecimiento de sus habilidades.

Palabras clave

aprendizaje; modelos educacionales; educación de pregrado en medicina.
How to cite: Cortés M, Guillén Olaya JF. Learning Styles of Undergraduate Medical Students. Univ. Med. 2019;59(2). doi: https://doi.org/10.11144/Javeriana. umed59-2.apre 


\section{Introduction}

According to the experiential learning theory proposed by Kolb $(1,2)$, learning is the process whereby knowledge is created through the transformation of experience. To apprehend the reality, the subject starts a cycle that includes living and observing a concrete experience, which allows him to reflect and generate provisional abstract concepts through the formation of ideas, generalizations and theories that are then tested and verified or modified through the creation of new experiences that, in turn, originate a new learning cycle.

When applied to the educational context, this theory proposes that for a student to have an effective learning, he/she needs to develop four basic skills that Kolb calls learning modes: (1) the student must be willing to live new experiences (concrete experience), (2) he/she must be able to observe and think the experiences out from different points of view (reflective observation), (3) must be able to integrate his/ her experiences and reflections into reasonable theories (abstract conceptualization) and (4) must apply these theories in decision-making and in problem solving (active experimentation) $(1,2,3)$. These four learning skills or modes are the poles of the two fundamental axes of the learning process: the apprehension axis (the way an experience is perceived or acquired), which goes from concrete to abstract, and the transformation axis (the way the experience is processed), which goes from action to reflection (Figure 1).
Figure 1.Kolb's Experiential Learning Model (1).

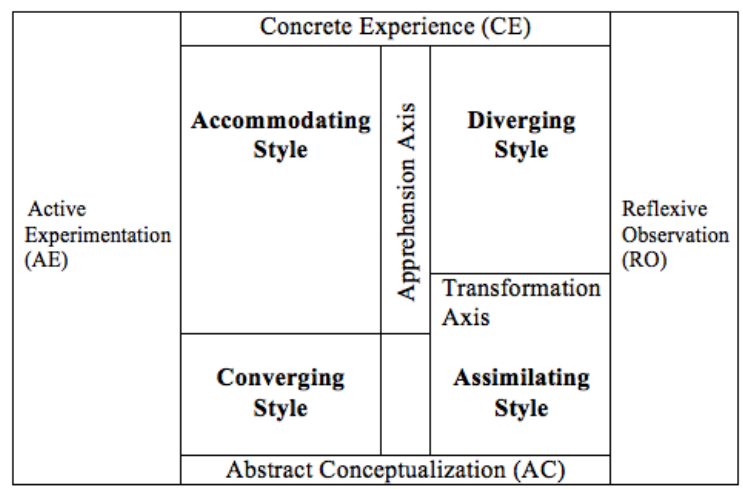

Effective learning requires four learning skills or modes (CE, RO, AC and AE) which constitute the poles of the two fundamental axes of learning: the apprehension of experience (concreteabstract continuum) and the transformation of experience (action-reflection continuum)

For various reasons, each person performs better in one of these learning modes and develops an own learning style: accommodating, diverging, assimilating or converging $(1,2)$. These four styles are determined by the combination of the different learning modes and are represented by the quadrants of Figure 1.

In the accommodating style, the student learns by doing; theory is only valid if it conforms to reality. These people stand out for their ability to take risks and implement actions; they tend to solve problems in an intuitive way by trial and error, and feel comfortable working with other people. The diverging style favors imaginative skills and the awareness of meanings and values. These people are interested in others and are guided by feelings; they view concrete situations from various perspectives, so they are good at solving problems that require the generation of ideas and the analysis of their implications. The assimilating student learns through inductive reasoning and focuses on abstract ideas and concepts. These people have the ability to create theoretical models by assimilating disparate observations into an integrated explanation. For them, the precision and logic of the theories is more important than their practical applicability; they are more interested in abstract ideas and concepts than in people. The converging student is characterized 
by learning through the application of knowledge to real problems and situations. These people tend to seek the practical use of ideas and theories following a logical sequence through a hypothetical deductive reasoning; they feel more comfortable dealing with technical tasks than with social and interpersonal discussions (1).

The accelerated increase in medical scientific knowledge in recent years has prompted the search for strategies to help students learn more effectively. Research in medical education has focused on identifying the factors that can affect the academic performance of students, and one of them is precisely the learning style (4). It is known that students of different careers tend to prefer certain learning modes and that these can be modified as they advance in their studies $(3,5)$. However, research conducted specifically on medical students presents mixed results and currently there are no data about the students of our faculty, information that could help the teachers to adapt the teaching practices to the students' specific needs and, consequently, favor a more effective learning and a better academic performance $(6,7)$. The objective of this work was to know the learning styles of the students of the first three semesters of medicine at the Pontificia Universidad Javeriana.

\section{Materials and methods}

The translation into Spanish of the first version of the Learning Style Inventory developed by Kolb in $1971(1,8)$, was applied to the students of the first three semesters of the Medical School of the Pontificia Universidad Javeriana, Bogotá, during the second academic semester of 2009.

The Learning Style Inventory is a selfdescriptive questionnaire with nine items, numbered from letter A to letter I. In each item the respondent is asked to order four words, corresponding to four learning modes, in the way that best describes the way they learn. Thus, in each item the four words are ordered with scores from 4 to 1 , assigning 4 points to the word that best represents the way they learn. Then, the scores assigned to each item are tabulated to find the values of the learning modes and the student's learning style (8).

As part of a regular academic activity, the survey was applied to the students who agreed to participate. In addition to the Learning Style Inventory, the survey requested additional sociodemographic information such as age, sex, semester, place of origin and type of school. Likewise, the students were asked to provide their name, in order to offer feedback about their learning style. The students were informed about the purpose of the study and the confidentiality of the information, as well as the voluntary nature of their participation and the possibility of subsequent feedback. A teacher conducted the survey and the students had 15 minutes to complete it.

The statistical package Stata 11.0 was used for the analysis. We calculated the means and the standard deviations for the scalar variables and the proportions for the categorical variables. To evaluate the presence of statistically significant differences between the mode variable and the learning style variable according to sex and semester non-parametric tests were performed, with a level of statistical significance of $5 \%$. The size of the sample was not calculated, given that it was a census study.

\section{Results}

Of the 249 students enrolled in the first three semesters of the Medical School of the Pontificia Universidad Javeriana, Bogotá in the second half of 2009, 204 agreed to participate in the study, which implied a response rate of $81.9 \%$. The ages of the students were between 16 and 38 years, with an average of 18.5 years $(\mathrm{SD}=1.95)$; $55 \%$ were women (113 students). Most came from private schools (95\%), bilingual (54\%) and religious (61\%) schools. $49 \%$ of the students came from Bogotá, and 3\% from another country.

The predominant learning mode was abstract conceptualization $(89 / 204,44 \%)$, followed by reflexive observation $(65 / 204,32 \%)$ and active experimentation $(64 / 204,31 \%) .17 \%$ of students (34/204) showed preference for two or more 
learning modes. No statistically significant differences were found in the proportion of learning modes by sex (chi square test, $\mathrm{p}=$ 0.069).

The most common learning style was the assimilating $(97 / 204,47 \%)$, followed by the converging style $(55 / 204,27 \%)$ (Figure 2). No statistically significant differences were found in the proportion of learning styles by sex (chi square test, $\mathrm{p}=0.184$ ) or by semester (chi square test, $\mathrm{p}=0.333)$.

Figure 2.Distribution of Learning Styles

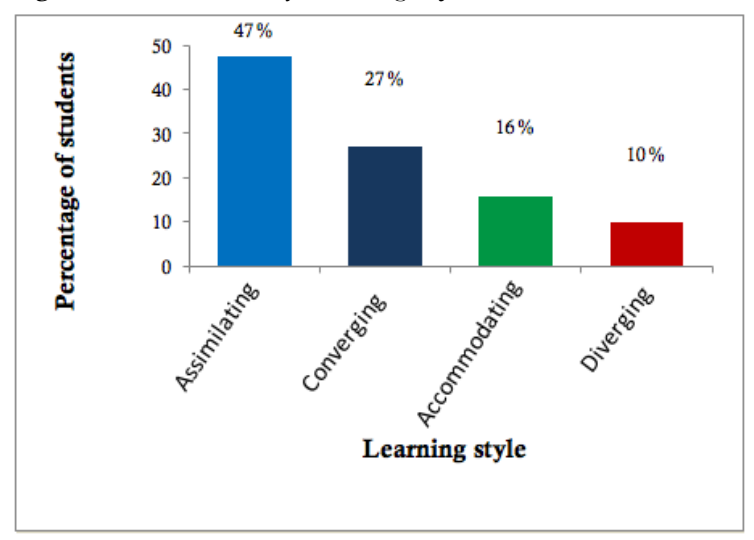

Regarding the apprehension axis, in the majority of students (152/204; 74\%) the abstract learning styles (assimilating and converging) prevailed over specific concrete styles (accommodating and diverging). This result was evident in both sexes.

Regarding the transformation axis, 57\% of students (117/204) prefer reflective styles (diverging and assimilating) over active styles (accommodating and converging). In men, the reflective style predominated $(59 / 91,65 \%)$, while in women the active and reflexive styles were equally distributed (49\% and 51\%, respectively). However, these differences were not statistically significant (chi-squared test, $p=0.052$ ), perhaps because of an insufficient sample size.

Figure 3 is a Kolb chart which shows the distribution of the learning styles of all the participants. The cross located in the lower right quadrant indicates the median position of the learning style of the entire sample, which corresponds to the assimilating style.
Figure 3.Distribution of the students in the Kolb's learning styles chart

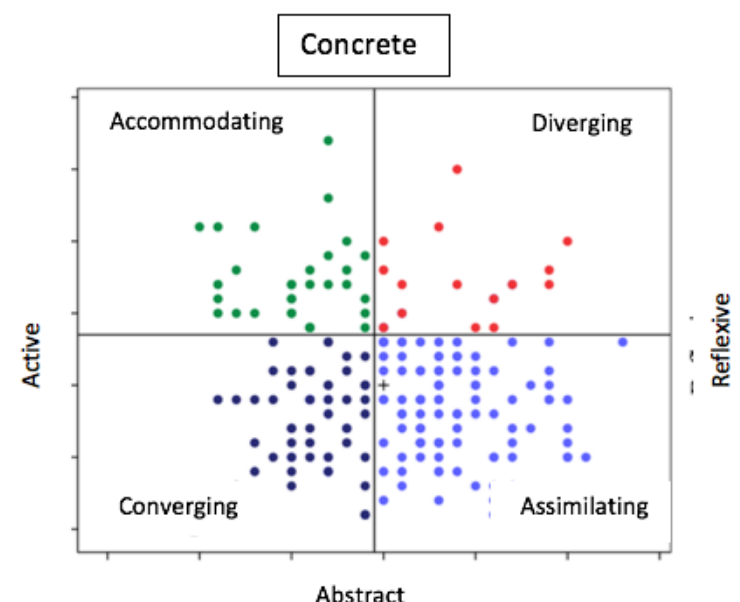

Each point can represent one or several students. The cross located in the lower right quadrant indicates the median position of the learning style of the entire sample

\section{Discussion}

The predominant learning styles in our students were the assimilating (47\%) and the converging (27\%), results comparable to those reported in the literature. In 2003 Bitran et al. (9) characterized the psychological types and learning styles of 270 students who entered the Medical School of the Pontificia Universidad Católica de Chile. Their study showed a higher prevalence of the assimilating (54\%) and converging (23\%) styles. In 2008, Borracci et al. (10) studied the learning styles of 199 medical students and residents of cardiology in Argentina. Of the 102 second-year students of medicine, the majority also presented an assimilating style $(71 \%)$. Other research in medical students $(5,11,12)$ found similar results; however, some studies conducted in the same student population in Turkey, Saudi Arabia and Pakistan $(13,14,15)$ found a predominance of the diverging and accommodating styles, which could be explained by the cultural characteristics of these regions.

Contrary to what is reported in the literature $(10,14,16,17,18)$, we did not find differences in the proportion of learning styles by sex. This is 
probably due to an insufficient sample size to perform a subgroup analysis.

Some researchers have observed that learning styles change as students advance in their studies $(5,12)$. However, we did not find differences in learning styles per semester, which could be explained by the fact that the sample consisted of students from the first three semesters of the career, who have not yet had contact with the clinical hospital setting, a learning environment that could contribute to a change in the learning style.

The most common learning mode was abstract conceptualization —congruent with the predominance of abstract learning styles (assimilating and converging) —, which indicates that our students prefer to acquire information through logical thinking, analysis of experiences and construction of theories; they focus on concepts and ideas and value precision, rigor and discipline. The assimilating student is able to conceive general theories from fragments of information and focuses more on the conceptual coherence of theories than on their applicability. On the other hand, the converging student, more pragmatic, is mainly interested in using the knowledge to solve concrete problems in real situations.

In recent years, research has shifted towards searching for relationships between learning styles and other academic factors, such as the students' performance or learning preferences. Among these studies it is worth mentioning the article by Gurpinar et al. (13), which evaluated the academic performance and satisfaction with different instructional methods of 170 firstyear medical students, in relation to their learning styles. Using a logistic regression analysis, these authors found that having an assimilating learning style was a predictor of student satisfaction with the traditional teaching method, compared with problem-based learning $(\mathrm{OR}=2.8 ; 95 \% \mathrm{CI}: 1.38-5.75)$, and a predictor of good performance in the theoretical block of exams $(\mathrm{p}=0.009)$. Other researchers have found similar results, and conclude that assimilating students value magisterial classes lectures and courses centered on theory- prioritizing reading, writing and the individual work; while converging students prefer courses that provide them with practical applications, with less emphasis on theory. The latter value the usefulness of workshops, laboratories, projects, case studies, team work and other pedagogical proposals that allow them to put into practice the knowledge acquired $(19,20,21)$.

Currently, the Faculty of Medicine of the Pontificia Universidad Javeriana is implementing a curricular change that went from a traditional teaching model to an integrated one. The new curriculum proposes a guiding thread focused on the study of cases that integrate knowledge from different areas of medicine; it offers the students an earlier contact with clinical practice and provides more opportunities to work in a team with their peers. In the light of the learning styles theory, this diversification of learning scenarios and methodologies into more practical contexts can benefit students who prioritize active learning modes, among which are converging students, which represent a considerable part of our population.

However, since the students who participated in this study belong to the previous curriculum, the question arises as to whether the curricular change affected in some way the preferred learning styles of our population, so it would be convenient to update this study in the students who are entering the faculty; in particular, it would be interesting to follow up a cohort of students to see if there are changes in the learning style during the career, and if these changes are motivated by the academic environment, as suggested by some authors $(5,22)$.

However, it is important to bear in mind that among the surveyed students there were exponents of each of the four learning styles. This finding should alert us to the need to offer the students a variety of learning contexts in order to benefit the whole group and stimulate the development or strengthening of skills that promote the effectiveness of learning in any situation they encounter $(6,23)$. The recommendation is in line with Kolb's theory, according to which learning is a continuous adaptive process in which the learner should 
ideally integrate the four learning modes to obtain a balanced learning style that responds to the various contents and learning situations (2). Felder goes even further: he states that a goal of higher education should be to equip the students with tools that favor the development of skills related to all learning styles, regardless of the students' personal preferences, because those skills are necessary to practice their profession effectively (24).

Our study has some limitations that should be mentioned. First, the majority of the students came from private, bilingual and faith-based schools, and half came from outside Bogotá. This characteristic is explained by the fact that the Pontificia Universidad Javeriana is a private university that receives students from all over the country. For this reason, caution should be exercised when extrapolating the results to students from other universities. Second, since our work is based on Kolb's experiential learning theory-that uses the Learning Style Inventory to determine the learning styles-it presents the limitations inherent to the model that, like others theories about learning, is not without criticism (25). Finally, since there are multiple models that classify learning styles in different ways, it was not possible to compare our results with other studies in similar populations of students, which were based on other theories and scales $(26,27)$.

\section{References}

1. Kolb D. Experiential learning: experience as the source of learning and development. Englewood Cliffs, NJ: Prentice Hall; 1984.

2. Kolb D, Boyatzis R, Mainemelis C. Experiential learning theory: previous research and new directions. In: Sternberg R, Zhang L, editors. Perspectives on cognitive, learning, and thinking styles. New Jersey: Lawrence Erlbaum; 2000.

3. Kolb D. Learning styles and disciplinary differences. In: Chickering A, editor. The modern American college. San Francisco: Jossey-Bass; 1981.
4. Ferguson E, James D, Madeley L. Factors associated with success in medical school: systematic review of the literature. BMJ. 2002 Apr 20;324(7343):952-7.

5. Gurpinar E, Bati H, Tetik C. Learning styles of medical students change in relation to time. Adv Physiol Educ. 2011 Sep;35(3):307-11.

6. Armstrong E, Parsa-Parsi R. How can physicians' learning styles drive educational planning? Acad Med. 2005 Jul;80(7):680-4.

7. Romanelli F, Bird E, Ryan M. Learning styles: a review of theory, application, and best practices. Am J Pharm Educ. 2009 Feb 19;73(1):9.

8. Kolb D. The learning style inventory. In: Kolb D, Osland J, Rubin I, editors. Organizational behavior: an experiential approach. 6th ed. Englewood Cliffs, NJ: Prentice Hall; 1995.

9. Bitran M, Zúñiga D, Lafuente M, Viviani P, Mena B. Tipos psicológicos y estilos de aprendizaje de los estudiantes que ingresan a Medicina en la Pontificia Universidad Católica de Chile. Rev Med Chil. 2003 Sep;131(9):1067-78.

10. Borracci R, Guthman G, Rubio M, Arribalzaga E. Estilos de aprendizaje en estudiantes universitarios y médicos residentes. Educ Médica. 2008;11(4):229-38.

11. Borracci RA, Arribalzaga E. Estilos de aprendizaje de Kolb en estudiantes de medicina. Med (Buenos Aires). 2015;75:73-80.

12. Engels PT, de Gara C. Learning styles of medical students, general surgery residents, and general surgeons: implications for surgical education. BMC Med Educ. 2010 Jan;10:51.

13. Gurpinar E, Alimoglu MK, Mamakli S, Aktekin M. Can learning style predict student satisfaction with different instruction methods and academic achievement in medical education? Adv Physiol Educ. 2010 Dec;34(4):192-6.

14. Buali WH Al, Balaha MH, Muhaidab NS Al. Assessment of learning style in a sample of 
saudi medical students. Acta Inf Med. 2013 Jan;21(2):83-8.

15. Danish KF, Awan AS. A study of student's learning styles in a medical institution in Pakistan. Rawal Med J. 2008;33:239-41.

16. Nuzhat A, Salem RO, Al Hamdan N, Ashour $\mathrm{N}$. Gender differences in learning styles and academic performance of medical students in Saudi Arabia. Med Teach. 2013 Jan;35 Suppl 1:S78-82.

17. Wehrwein EA, Lujan HL, DiCarlo SE. Gender differences in learning style preferences among undergraduate physiology students. Adv Physiol Educ. 2007 Jun;31(2):153-7.

18. Slater JA, Lujan HL, DiCarlo SE. Does gender influence learning style preferences of first-year medical students? Adv Physiol Educ. 2007 Dec;31(4):336-42.

19. Campeau AG. Distribution of learning styles and preferences for learning environment characteristics among Emergency Medical Care Assistants (EMCAs) in Ontario, Canada. Prehosp Disaster Med. 1998;13(1):55-62.

20. Gardner BS, Korth SJ. A framework for learning to work in teams. J Educ Bus. 1998 Sep;74(1):28-33.

21. Svinicki MD, Dixon NM. The Kolb model modified for classroom activities. Coll Teach. 1987;35(4):141-6.

22. Shaikh A. Learning styles and satisfaction with educational activities among paediatric physicians at King Abdulaziz Medical City Jeddah. J Taibah Univ Med Sci. 2015;10(1):102-8.

23. Loo R. Kolb's learning styles and learning preferences: is there a linkage? Educ Psychol. 2004 Feb;24(1):99-108.

24. Felder RM, Brent R. Understanding student differences. J Eng Educ. 2005;94(1):57-72.

25. Cassidy S. Learning styles: an overview of theories, models, and measures. Educ Psychol. 2004;24(4):419-44.

26. Samarakoon L, Fernando T, Rodrigo C. Learning styles and approaches to learning among medical undergraduates and postgraduates. BMC Med Educ. 2013 Jan;13:42-7.

27. Lujan HL, DiCarlo SE. First-year medical students prefer multiple learning styles. Adv Physiol Educ. 2006 Mar;30(1):13-6. 